\author{
Textbook: Focus on Students' National Identity
}

\title{
Integrating an Electronic Textbook on a Foreign Language into the M.E.S.-System
}

\author{
Andrey A. Kolesnikov¹ (a), Irina V. Bogovskaya (b), Yulia V. Krasovitskaya (c), \\ Nataly A. Spichko (d)
}

(a) Ryazan State University named after S.A.Yesenin, 390000, Ryazan (Russia), 46, Svobody; Moscow City University, 129226, Moscow (Russia), 4-1, $2^{\text {nd }}$ Selskokhoziastvenny Proezd;

(b) Moscow City University, 129226, Moscow (Russia), 4-1, $2^{\text {nd }}$ Selskokhoziastvenny Proezd;

(c) Moscow City University, 129226, Moscow (Russia), 4-1, $2^{\text {nd }}$ Selskokhoziastvenny Proezd;

(d) Moscow City University, 129226, Moscow (Russia), 4-1, $2^{\text {nd }}$ Selskokhoziastvenny Proezd;

Kolesnikov@mgpu.ru

\begin{abstract}
The article discusses the problem of modernizing a new generation foreign language electronic textbook as well as an electronic platform that organizes the entire educational process. The urgency of the problem lies in the fact that the need for an urgent transition to distance learning arisen all over the world has highlighted the shortcomings of the current Russian alternative electronic school education system. The purpose of the article is to identify its shortcomings and suggest ways to eliminate them. The main method is the examination of the Russian electronic educational system in the field of disciplines - German and English as foreign languages. The work of the authors of the article as experts of the educational platform "Moscow Electronic School" (MES) made it possible to combine the valuable information presented here about current electronic textbooks and collect observations about the content and technical components of the proposed scenarios of electronic lessons. The analysis concludes that MES is currently the most developed and demanded tool of the Russian electronic educational system. First of all, these include the creation of a unified interactive educational media space and the organization of synchronized work of the teacher and students in three formats: full-time, remote, full-time-distance. This implies the smooth interaction of three digital spaces: the screens of the teacher, the student, and the interactive whiteboard. The practical significance of the research results is based on identifying the main ways to merge the electronic textbook and the electronic platform that supports its operation.

Keywords: foreign language, electronic textbook, Moscow electronic school.
\end{abstract}

(C) 2021 Andrey A. Kolesnikov, Irina V. Bogovskaya, Yulia V. Krasovitskaya, Nataly A. Spichko This is an open access article distributed under the terms of the Creative Commons Attribution License (CC BY 4.0), which permits unrestricted use, distribution, and reproduction in any medium, provided the original author and source are credited.

Published by Moscow City University and peer-reviewed under responsibility of TSNI-2021 (Textbook: Focus on Students' National Identity)

\footnotetext{
${ }^{1}$ Corresponding author. E-mail: kolesnikov@mgpu.ru
} 


\section{Introduction}

The distance learning mode, by necessity introduced everywhere in 2020 and becoming one of the basic options in the organization of the educational process, raises the need to revise the requirements for an electronic textbook (hereinafter - ET) as a leading educational tool. Today, there is no doubt that an electronic textbook should equally effectively ensure the implementation of full-time, mixed and fully distance learning modes of a foreign language (hereinafter referred to as FL), while using all the possibilities that the digital environment provides and which have proven their effectiveness in organizing the educational process.

\section{Purpose and objectives of the study}

This article attempts to substantiate two theses that, in our opinion, will contribute to solving the named problem:

A) ET should provide intermedia learning (V. Frederking, K. Prümm, J. Wermke, I. Rajewsky and others, see (Frederking, 2018)), which implies the ability to quickly switch between the mentioned modes without loss of content quality, variability of forms of organization of the educational process while maintaining existing and future opportunities for online learning;

B) ET must be integrated with the interface of the Russian educational online platform "Electronic School" (in particular, "Moscow Electronic School" known as MES), which necessitates conceptual and technical revision of both the ET itself and the MES.

\section{Literature review}

The fundamental foundations of the theory of a textbook on FL were laid in the Russian methodology in the 1970s by I.L. Bim. The basic provisions of this theory remain unshakable to this day. However, as the experience of the ubiquitous distance learning mode in Russian schools in 2020 showed, a number of essential characteristics and principles of the textbook were violated or difficult to implement. In particular, objective difficulties arose with the following characteristics (see about them in more detail in Bim (1977)):

- ensuring the implementation of the main methodological categories in the learning process of the foreign language (there was a significant violation of the principles of accessibility and feasibility, systematicity, activity, the principle of the communicative orientation of training was implemented with significant restrictions); 
- modeling and recreation through the textbook of the entire learning system of the FL, taking into account all its phenomena and processes (a number of modes of operation - pair, group, etc. - turned out to be almost unavailable when switching to online learning);

- the adaptive function of the textbook (the classical textbook could not effectively manage the pedagogical process in the new conditions and was unable to fully adapt to online learning);

- management of educational activities due to the system of exercises (not all types of exercises were available for execution; especially big problems arose with the formation of pronunciation skills, the implementation of different types of control, the implementation of exercises focused on different forms of class work);

- unification of all other learning tools around itself (many non-digital tools turned out to be inaccessible in the digital environment).

Most of the problems mentioned above were caused by the changed learning environment, namely the abrupt change in the educational environment: the transition from predominantly analogue to fully digital. A violation of the principle of intermedia was found, since the educational Internet space, which had previously had auxiliary functions, ceased to interact with the classic "offline" environment, while the interconnection of funds was partly lost. The classical compatibility of teaching aids was disrupted, the strategies developed for their combination and the usual methods of didactic "media switching" ("Medienwechsel") ceased to work (Frederking, 2018). For example, such seemingly ordinary transitions from working with the classic text of a textbook to filling in the gaps in the workbook (subject to control of the implementation of the work by the teacher), mutual checking based on audio (visual) material and to further work with handouts turned out to be difficult even for a trained teacher. It became clear that the educational process is not violated only if absolute analog-digital continuity is realized: all non-digital means used in classroom and independent work must have digital analogues. In reality, most of the text and illustrative-visual materials that the teacher is used to using in the classroom have not previously been uploaded to the digital environment. The functionality of well-known educational platforms (MS Teams, Google Classroom, etc.) turned out to be insufficient, since they were originally designed either as an addition to full-time education (Beliaeva, Samorodova and Fedorova, 2020), or for blended learning ("blended learning"), in which part of the cognitive activity of students is lesson under the guidance of a teacher, and part of it is carried out in a distance form (Distantsionnoye obucheniye ..., 2009). That is, in most cases, they are focused on a distance format that complements full-time forms of classes, but are not intended to fully compensate for classroom work. 
The electronic version of the textbook should contribute to the solution of this problem as an important element of the digital modernization of the educational process in the field of learning foreign languages (Tareva and Yazykova, 2018). The theory and practice of developing an electronic textbook is actively developing in Russia and abroad. The analysis showed that the term "electronic textbook" is interpreted differently by domestic and foreign researchers (Open at the Margins ..., 2020; Kordes, 2014). We are impressed by the point of view according to which a new generation of ES is considered as a modern interactive software and methodological complex, among the main characteristics of which it should be noted:

- prevalence of illustrative intermedia material over text, in contrast to the traditional printed textbook format (Ahlrichs and Macgilchrist, 2017);

- the use of multimedia capabilities integrated into the content aspect of the content of individual modules: podcasts, audio fragments, video clips, animation, etc. (Kordes, 2014; Krasovitskaya and Bazhanov, 2019);

- the presence of hyperlinks providing a nonlinear branched structure of the content of the modular organization of the program material (Gerasimenko, 2020);

- quick "feedback" thanks to built-in test and control tasks, exercises with the possibility of self-monitoring and assessment (Gerasimenko, 2020);

- simplicity and convenience of the teacher's creative use of interactive audiovisual and textual information of the basic and additional sections of each module (Evans, 2016);

- maximum differentiation and individualization of the process of mastering a foreign language in the digital environment of an interactive software and methodological complex (DeRosa and Robinson, 2017).

In recent years, the term "SMART-textbook" has been encountered in publications: a promising educational tool that should replace both the paper and the current electronic textbook in the near future. Summarizing a number of relevant studies in the field of linguodidactic potential of "Smart-technologies", N.V. Chernyshkova defines SMART textbooks as educational content integrated into an interactive learning environment using the capabilities of the social environment. Such textbooks are characterized by practical orientation, the presence of graphic, video and audio material, an individual learning path, interactive tools for interacting with a teacher, a testing system, a content commenting system, a content assessment system, self-complementarity and self-actualization (Chernyshkova, 2018). Obviously, we are talking about a new generation of ET, which integrates all the existing digital learning capabilities of FL 
and has an open architecture.

It should be assumed that the effective functioning of such a textbook is possible in such a digital online environment, which, on the one hand, provides the necessary intermedia learning of a foreign language, and on the other hand, supports all modern interactive online learning technologies. To date, the methodology has accumulated a large theoretical and practical experience in the study and testing of each individual technology, classification and justification of the training potential of Internet resources have been proposed, taking into account linguodidactic specifics (Zaitsev and Vilden, 2020). Thus, typologies have been substantiated and the possibilities of organizing classroom and independent work on foreign language using educational blogs, podcasts and social networks are described (Goltsova and Protsenko, 2019; Dronov, 2019; Sysoev, 2020), touched upon the design of a "mobile space" and the problem of gamification in teaching foreign languages (Titova and Chikrizova 2019; Titova, Kotkova 2019), a method of using Wiki technology to create a virtual learning environment for a foreign language course has been developed (Nazarenko, 2017; Sysoev, 2019), a fundamental study was carried out, which made it possible to identify the conditions and strategy for the design of individual educational trajectories in the information educational environment when teaching foreign languages (Krasnopeeva, Shevchenko and Gural, 2020), etc. Among the promising ways for organizing training in foreign languages, researchers are increasingly paying attention to a multilingual / multicultural network educational project, the main features of which are the distribution of tasks in accordance with the individual set of competencies of the subjects of activity and correlation with objective reality, which provides access to the latest authentic information in a foreign language, provides students with the opportunity to gain experience of intercultural communication, to form skills and behaviors in a foreign cultural environment, intellectual flexibility and tolerance (Biryukova et al., 2018). The digital content used in this case should ensure the orientation of the educational content on the development of the cognitive potential of the student with an emphasis on the subject-activity component of the educational process, which actualizes the shift in emphasis from reproductive assimilation of knowledge to active mastering of universal methods of cognition of the surrounding reality in the process of creative awareness of the foreign language the linguistic code, when significant changes occur in the mental processes and psychological characteristics of the student's personality (Bogovskaya, 2016).

However, it should be stated that these studies are predominantly aspectual in nature and are not united by the task of designing an integrated online system (virtual environment) that ensures the functioning of ET. In addition, as the experience of total distance learning has shown, the currently existing electronic forms of textbooks were unable to ensure the proper continuity of offline and online modes. First, there was insufficient experience with ET; in addition, not all textbooks have (or are available) electronic-interactive 
versions. Secondly, even the best examples of ET could not fully solve the problem of regulating the interaction of a student, teacher and educational environment - that is, the existing ET do not have the intermedia character required in modern conditions. Thus, it becomes obvious the need for a fundamentally new integrated resource that would provide convenient (not requiring additional labor input from the teacher) synchronization of teaching aids and, at the same time, the continuity of the content, forms and methods of full-time and distance learning of foreign languages. Obviously, such a resource should include: a) a new educational platform, the functionality of which allows organizing the interaction of the student's learning space, the teacher's educational activities and their inclusion in the external educational environment - i.e. implement a virtual educational process as close as possible to the basic characteristics of offline education; b) a new type of ET, integrated into the named platform and providing educational and regulatory functions of learning a language.

\section{Methodology}

The methodological basis of the study was the works of Russian and foreign researchers I.L. Bim, A.A. Kolesnikov, P.V. Sysoev, E.G. Tareva, V. Frederking, N.V. Yazykova and others. To solve the set tasks, a set of theoretical and empirical research methods was used: analysis, generalization, comparison, interpretation, extrapolation, design, modeling, study and expert assessment of the digital environment of the Russian educational online platform "Electronic School". The main research method was the expertise of the Russian electronic educational system and the educational institutions located in it. During 20182020 the authors of the article were experts of the educational platform "Moscow Electronic School" (MES) in the field of the discipline "Foreign languages" (English and German as foreign languages). During this period, an expert evaluation of more than 300 electronic lesson scripts (or scenarios) in English and German was carried out, as well as more than 100 electronic textbooks and manuals uploaded on the MES environment in the same subjects. The experts also had the opportunity to study the online constructor used in this platform and develop a number of their own electronic lesson scripts with its help. Additionally, we analyzed the electronic forms of textbooks in English and German, presented on the official website of the publishing house "Prosveshchenie" (in the amount of 12 pieces), as well as studied foreign experience in using educational online platforms and electronic textbooks based on current publications.

\section{Results}

Generalization of our expert experience and current publications on the problem of using the educational 
online environment in teaching foreign languages ( Roche, 2008; Distantsionnoye obucheniye ..., 2009; Kolesnikov, 2015; Chernyshkova, 2018; Frederking, 2018; Titova and Harlamenko, 2018; Sysoev 2019, 2020) made it possible to determine the basic characteristics of an online educational platform capable of supporting the functionality of the ET integrated into it. These include the following: availability of intuitive (for the teacher) development and administration tools; the availability of written and audiovisual communication channels for teachers and students; the ability to create exercises and assignments of different types, corresponding to the typologies of exercises accepted in the methodology, as well as assign individual, pair and group assignments; the ability to create a library of resources (databank with educational materials); the presence of a "virtual board", i.e. spaces for collaboration, presentation of materials and learning outcomes; the possibility of organizing interaction in different formats (in accordance with the existing learning technologies of the foreign language); the possibility of organizing different types and forms of control; support of the point grading system; support for integration with social media, that is, with an authentic natural communication environment. Along with this, the described platform should provide a single educational media space for different formats or learning models. This means that the platform should support FL learning in three formats (modes), and allow switching between them at any time without loss. Two of them are face-to-face and remote (including online) modes. All materials used must be in a single digital environment, which ensures the continuity and continuity of classroom and home (independent, distance) learning activities. In addition, this platform should provide for another, completely new learning model: synchronized face-to-face-distance mode, in which part of the students is engaged in a traditional school classroom, and the other part is present in the same lesson remotely (for example, using the platform installed on the home computer) and performs the same tasks, carries out the same types of work, and interacts with the teacher and other students just as freely as the full-time students.

The Moscow Electronic School (hereinafter referred to as MES) may become such a tool in the future, the potential of which makes it possible to create a universal digital space for organizing a face-to-face, remote and synchronized educational process. The versatility of the MES is due to the didactically thought-out technology of "scenarios" (lesson scripts) that this platform supports. "Scenario" is a system of interaction of three digital spaces (a system of three screens), which together form the educational environment of the lesson at each of its stages. These three screens include: a student's screen or tablet, a teacher's screen or tablet, an interactive whiteboard as a common classroom space. When designing each stage of the lesson, all three screens are filled taking into account the tasks of this stage, the provided forms and methods of organizing work, as well as the planned specifics of interaction between the teacher and students.

At the same time, as our expert analysis shows, the MES system needs significant technological 
improvement for the effective implementation of the above functions and the possibility of integrating ES with it.

Now the system is almost completely devoid of the interactivity necessary for learning FL. MES must be equipped with audio and video channels of interaction between teacher and students, which is especially important in the context of distance and "synchronized" learning. In addition, a chat or messenger should be built into the platform. The teacher and students should be able to interact (audiovisually and/or through textual interaction) in different modes: frontally, in the form of the whole class discussion, in group and pair work. For this, the screens of students and teachers (including communication channels) must quickly and intuitively adjust to the appropriate format of work, as well as ensure switching to the required mode of the third screen (whiteboard).

Attention should also be paid to the problem of screen pairing. When working with the MES, there is an urgent need to add control functions on the screens of the teacher and students. Now the screen system is represented by simple static slides. The teacher should be given the opportunity to freely control the students 'screens: for example, in real time, modify, add or disable text and/or multimedia materials on the board and students' screens, transfer student screens to different modes of collaboration (pair, group), etc. Students should be able to carry out different types of work on their screens, including group work. At the same time, there should be a field for group work on the screen, in which the actions of all members of the group are synchronized. If necessary, the student should be able to transfer information to the teacher's tablet, connect to the "board", etc.

The MES system needs an intuitive and easy to use slide builder. The functions of the designer should be supplemented with the division of screens into functional fields (zones of group and individual work, a general information field, etc.), the addition and editing of text, graphic, audiovisual and multimedia objects, a set of functional buttons with which communication is provided with other screens (for example, "select a slide" (in case of differentiated tasks), "organize a joint work", "add to the group", "start the presentation", "send to the teacher for review", etc.). Now the named functions are either completely absent, or require substantial revision (for example, when constructing slides in the current system, problems may arise even with adding and editing tables).

Only under the condition of the indicated improvements, the MES platform can be considered as a suitable basis for integrating a new generation of ET that implements intermedia learning. What should be an ET for a FL learning from a technical point of view?

First of all, according to the idea of the developers of the MES system, the lesson scripts should be 
consistent with the materials of electronic forms of textbooks and teaching aids uploaded to the MES or developed directly in the MES environment. At the same time, as our analysis of textbooks and manuals on foreign languages posted on the platform shows, at present the MES script constructor does not interact well with the ET interface (or does not interact at all). Many electronic versions of textbooks are scanned PDF-versions of printed manuals, which is completely inconsistent with the capabilities of the three-screen MES system.

It is obvious that the electronic teaching materials should have the function of automatic interaction between the student's manual (which in the electronic version, apparently, can combine the textbook and workbook) and the teacher's electronic book; at the same time, the educational content of the ET and the methodological material of the book for the teacher must have the function of synchronization with the system of screens of the lesson script.

So, for example, when a teacher moves to the screen of his tablet connected to the MES, recommendations for working with text from the methodological section of the e-book for the teacher, then the educational material (text and accompanying exercises) should automatically appear on the screen of the student's tablet, and on the screen boards - auxiliary materials (infographics, linguistic and cultural comments, etc.). The functionality of the textbook should allow the teacher to either offer all students uniform tasks (that is, to provide a common filling of the slide for the whole class), or to provide for differentiation, in which students independently choose a slide with a task of interest to them. So, in the above example with the text, the choice of students can be offered a slide where individual work with this text is provided, or a slide aimed at organizing group work using cooperative reading. The teacher should be able to modify the material on the screens at his own discretion.

Let us also pay attention to the fact that the functionality of the described ET should take into account the actual requirements of sanitary and epidemiological rules and regulations (SanR\&S) in the part "Duration of continuous use of technical teaching aids in the classroom." In accordance with these requirements, screen work (in the presence of a liquid crystal monitor) should take no more than 30 minutes in grades 5-6 and 35 minutes in grades 10-11 during one lesson. This means that the development of ET should imply a particularly careful and detailed planning of the forms of material presentation. In our opinion, it is reasonable to consider the norm of no more than $70 \%$ of screen material (texts for frontal or group work, visual material, exercises for screen writing, including homework) from the entire content of each section. Screen information should be supplemented with an enhanced audio component (in this case, the audio material will also perform compensating functions: listening, audio chat) and independent off-screen work.

\section{Discussions}


As a discussion, we will offer our recommendations regarding those functions with which, in our opinion, it is necessary to supplement the MES screen system for full integration of the described type of control unit with it.

The student's screen should combine the functions of an electronic textbook and a workbook, which means it should contain texts (traditional and multimedia), visual material, exercises, additional materials (including links to Internet resources), interactive fields for students to complete different types of tasks and sending work results to the teacher's tablet. Secondly, as noted, it must ensure the organization of joint activities of students, as well as different forms of interaction between students and teachers. For example, when completing a group assignment, students' screens should open up space for co-creation and editing of text (based on Wiki technology (Nazarenko, 2017; Sysoev, 2019, 2020), audiovisual content and/or presentation. Students' screens should be linked to the teacher's tablet: if necessary, the teacher can connect to a group or to an individual student's tablet, communicate via chat or an audio communication channel, listen to the answer, consult, send additional materials, exercise control. Thirdly, the student's screen space should allow for the differentiation or individualization of the work provided for by the ET tasks. For example, a student may be offered several options for the educational "screen" (which includes an assignment and an interactive space to complete it). In order to differentiate, the work-at-stations methodology, transferred to the MES format, should be supported: students are united in groups, synchronizing their tablets, and choose from the list of options the screen of interest to them, on which the task of a certain station is located. These can be screens-stations, providing for working with text, video, creating your own oral or written statement, etc. Students choose the required number of screens in the sequence that they consider optimal for themselves. At the end of the specified time, the screen is automatically closed and the results of the work are sent to the teacher's tablet.

In the mode of independent work, the student's screen should become an individual learning space, where tasks are received, where they are completed, and also independent individual or group (when interacting with other students) activities are implemented. This space should have a place for storing rough, unfinished materials, as well as a field for presenting the final results of the work, displaying them in a common workspace (on the board) and/or transferring materials to the teacher's tablet for checking

The shared screen (interactive whiteboard) is used to demonstrate text and audio-visual information to the entire class. It can act as a whiteboard for teacher and students to post, provide a visual aid, and allow students to present their individual or group results from their tablet to the entire class. Part of the board can serve as a reference point for individualized goal-setting and reflection, as well as for the choice of tasks with the differentiation provided for in the ET. For example, when organizing the aforementioned work-at- 
stations, a list of all stations with brief annotations should be presented on the general screen. In addition, the common screen should serve as a space for different types of cooperative activities: for example, for creating different types of associagrams (semantic, grammatical field, graphical presentation of text content, etc.), cooperative writing, etc. In this case, the contribution of each student is highlighted in a special color (the mentioned Wiki technology). Note also that each student must be technically able to switch their tablet to an image from the shared screen. This is especially necessary for remote and synchronized modes of organizing classes.

In the independent work mode, the common screen (whiteboard) should become a common study space, where links to the necessary materials (dictionaries, reference books, texts, audiovisual and multimedia materials, etc.), a field for general interaction (for example, a common forum, chat, etc.), which, if necessary, can be divided into individual student blogs (where each student posts their materials for general information, and other students and the teacher can leave comments) and space for joint creative work (for example, cooperative writing ).

The teacher's screen should combine two control functions. Firstly, we are talking about the methodological management of the educational process. The teacher's screen contains methodological comments and recommendations for organizing the current stage of the lesson, as well as the expected results of assignments. This information is carried over into the lesson script from the ET teacher e-book. Secondly, the teacher's screen should allow technical control of other screens: connect to students' screens, transfer (if necessary) additional content, unite students into teams, quickly modify the content on the common screen, etc.

\section{Conclusion}

In this article, we presented the main conclusions that we obtained in the course of expert work within the framework of the MES regarding the directions of improving the ET technology in FL learning and the electronic platform that supports its work.

1. ET of a new generation should provide intermedia communication of all modes of organization of the educational process - full-time, remote, synchronized - as well as fast switching between them. To do this, it should be an open digital educational space that supports interaction between the subjects of the educational process in all of the above modes, which has sufficient flexibility to differentiate and individualize the educational process, implement the most suitable forms and methods of teaching depending on the chosen mode, and also support the function of self-actualization or updates.

2. To implement these requirements, the educational institution must be configured to support and ensure 
the interaction of the three educational spaces of the lesson and independent work: the space of the student, the space of the teacher, and the common space of the class. In our opinion, only in this case will the specificity of learning FL in each of the modes be fully taken into account.

3. The technological support of ET work in the system of three educational spaces should be taken over by the educational platform, into which ET is integrated. The MES platform seems to be the most promising in this regard. The versatility of this platform allows not only to implement the principle of intermedia, but also to create a single media space for different learning formats, which favorably distinguishes the MES from other educational platforms. At the same time, the implementation of the described potential (in particular, in relation to the training of foreign languages) will become possible only if this platform is improved. The main guidelines for finalizing the MES were proposed by us in this article.

\section{Acknowledgements}

Our thanks to Moscow City University for given opportunity to work in the MES system.

\section{References}

Ahlrichs, J. \& Macgilchrist, F. (2017). Medialität im Geschichtsunterricht. Die Rolle des Schulbuchs beim Vollzug von "Geschichte". Zeitschrift für interpretative Schul- und Unterrichtsforschung. 6, 14-27.

Beliaeva, I.G., Samorodova, E.A., Fedorova, A.A. (2020). Rol' distantsionnykh obrazovatel'nykh tekhnologiy pri izuchenii inostrannogo yazyka $v$ Rossii [The role of distance learning technologies in the study of a foreign language in Russia]. Inostrannye yaziki v shkole [Foreign languages at school], 9, 38-43.

Bim, I.L. (1977) Metodika obucheniya inostrannym yazykam kak nauka i problemy shkol'nogo uchebnika [The methodology of foreign language teaching as a science and the problems of a school textbook]. Moscow: Russkiy yazik [Russian language].

Biryukova, E.V., Bogovskaya, I.V., Molchanova, M.A., Morozova, E.A., Semenova, G.Y., Shvedova, I.V. (2018). Setevoy proyekt kak instrument realizatsii proyektnoy deyatel'nosti v shkole i vuze [Network project as a tool for the implementation of project activities at school and university]. Obrazovatel'noye prostranstvo $v$ informatsionnиуи epokhu (EEIA-2018) [Educational space in the information age] (pp.289-298). Moscow: FGBNU «Institut strategii razvitiya obrazovaniya RAO» [FSBSI "Institute of education development strategy of the Russian Academy of Education]. 
Bogovskaya, I.V. (2016) Integratsiya issledovatel'skikh umeniy i universal'nykh uchebnykh deystviy na urokakh inostrannogo yazyka [Integration of research skills and universal learning activities in foreign language lessons]. Razvivayushchiye aspekty lingvisticheskogo obrazovaniya: problemy $i$ perspektivy [Developing aspects of linguistic education: problems and prospects] (pp.27-33). Nijniy Novgorod: NGLU [NSLU].

Chernyshkova, N.V. (2018). SMART-tekhnologii v prepodavanii inostrannogo yazyka [SMARTtechnologies in teaching a foreign language]. Filologicheskiye nauki. Voprosy teorii i praktiki [Filological sciences. Problems of theory and practice], 2(1), 211-214. https://doi.org/10.30853/filnauki. 2018-2-1.59

DeRosa, R \& Robison, S. (2017). From OER to Open Pedagogy: Harnessing the Power of Open. Jhangiani, R S and Biswas-Diener, R. (eds.) Open: The Philosophy and Practices that are Revolutionizing Education and Science. London: Ubiquity Press, 115-124.

Distantsionnoye obucheniye v profil'noy shkole [Distance learning in a specialized school] (2009) Polat E.S., Petrov A.E., Tatarinova M.A. et al. (Eds.). Moscow: Akademia [Academy].

Dronov, I.S. (2019). Blog uchebnoy gruppy kak odna iz sovremennykh Internet-tekhnologiy v obuchenii inostrannomu yazyku [Study group blog as one of the modern Internet technologies in teaching a foreign language]. Vestnik Tambovskogo universiteta [Bulletin of Tambov university], 24 (180), 6169.

Evans, K. (2016). Beyond a logic of quality: Opening space for material-discursive practices of 'readiness' in early years education. Contemporary Issues in Early Childhood, 17, 65-77.

Frederking, V. (2018). Mediendidaktik Deutsch: Eine Einführung. V.Frederking, A.Krommer, K.Maiwald (eds.). Berlin: Erich Schmidt Verlag.

Gerasimenko, I.E. (2020). Elektronisches Lehrbuch im Bildungsprozess. Problemy nauchnoy mysli [Problems of scientific thought], 1(3), 41-43.

Goltsova, T.A. \& Protsenko, E.A. (2019). Ispol'zovaniye blogov i sotsial'nykh setey v protsesse obucheniya inostrannomu yazyku [Using blogs and social networks in the process of teaching a foreign language]. Yaroslavskiy pedagogicheskiy vestnik [Bulletin of Yaroslavl pedagogical institute], 3, 62-68. https://doi.org/10.24411/1813-145X-2019-10417 
Kolesnikov, A. (2015). Didaktische Grundlagen des berufsorientierenden Fremdsprachenunterrichts im Rahmen der linguistischen Ausbildung. Fremdsprachliche Lernprozesse: Erträge des 4. Bremer Symposions zum Lehren- und Lernen von Fremdsprachen. Bochum: AKS-Verlag, 239-250.

Kordes, R. (2014). Elektronische Schulbücher aus fachdidaktischer Perspektive. Analyse der Einsatzpotenziale und Entwicklung eines Prototyps für den Wirtschaftsunterricht. Masterarbeit. Universität Oldenburg.

Krasnopeeva, T.O., Shevchenko, A.I., Gural, S.K. (2020). Proyektirovaniye individual'nykh obrazovatel'nykh trayektoriy $\mathrm{v}$ informatsionnoy obrazovatel'noy srede [Designing individual educational trajectories in the information educational environment]. Yazik $i$ kultura [Language and culture], 51, 153-176. https://doi.org/10.17223/19996195/51/8

Krasovitskaya, YU.V. \& Bazhanov A.Ye. (2019) Olimpiada po nemetskomu yazyku: primery zadaniy [Olympiad in German: examples of assignments]. Inostrannye yaziki v shkole [Foreign languages at school], 1, 74-80.

Nazarenko, A.L. (2017). Tekhnologiya Wiki dlya sozdaniya virtual'noy obuchayushchey sredy distantsionnogo kul'turologicheskogo kursa «The World of Britain» [Wiki technology for creating a virtual learning environment for the distance cultural course]. Yazik $i$ kultura [Language and culture], 40, 244-253. https://doi.org/10.17223/19996195/40/17

Open at the Margins. Critical Perspectives on Open Education (2020). Bali, M., Cronin, C., Czerniewicz, L., DeRosa, R., Jhangiani, R. (Eds.).

Roche, J. (2008). Handbuch Mediendidaktik: Fremdsprachen. Ismaning: Hueber.

Sysoev, P.V. (2019). Informatsionnyye i kommunikatsionnyye tekhnologii v lingvisticheskom obrazovanii [Informationand communication technologies in linguistic education]. Moscow: Librokom.

Sysoev, P.V. (2020). Organizatsiya proyektnoy deyatel'nosti obuchayushchikhsya na osnove sovremennykh informatsionnykh i kommunikatsionnykh tekhnologiy i upravleniye proyektami [Organisation of project activities of students based on modern information and communication technologies and project management]. Inostrannye yaziki $v$ shkole [Foreign languages at school], 9, 15-28. 
Tareva, E.G. \& Yazikova, N.V. (2018). Faktory modernizatsii shkol'nogo obrazovaniya v predmetnoy oblasti «Inostrannyye yazyki» [Factors of modernization of school education in the subject area "Foreign languages"]. Inostrannye yaziki v shkole [Foreign languages at school], 4, 2-8.

Titova, S.V. \& Harlamenko, I.V. (2018). Informatsionno-kommunikatsionnaya kompetentsiya uchiteley i prepodavateley inostrannogo yazyka: struktura, urovni, sposoby formirovaniya [Information and communication competence of teachers and teachers of foreign languages: structure, levels, ways of formation]. Inostrannye yaziki $v$ shkole [Foreign languages at school], 8, 2-7.

Titova, S.V. \& Kotkova, I.S. (2019). Metodicheskiye osnovy razrabotki mobil'nogo klassa dlya obucheniya inostrannym yazykam $\mathrm{v}$ starshey shkole [Methodological foundations for developing a mobile classroom for teaching foreign languages in high school]. Vestnik Moskovskogo universiteta. Seriya 19: lingvistika i mezhkul'turnaya kommunikatsiya [Moscow University Bulletin. Series: Linguistics and intercultural communication], 2, 103-114.

Titova, S.V.\& Chikrizova, K.V. (2019). Geymifikatsiya v obuchenii inostrannym yazykam: psikhologodidakticheskiy i metodicheskiy potentsial [Gamifiction in teaching foreign languages: psychological, didactic and methodological potential]. Pedadogika i psihologia [Pedagogy and psycology], 1, 135-152.

Zaitsev, G.M. \& Vilden Sh. (2020) Onlayn-obucheniye inostrannomu yazyku: s chego nachat' i o chem neobkhodimo pomnit' [Online learning a foreign language: where to start and what to remember]. Inostrannye yaziki v shkole [Foreign languages at school], 9, 44-49. 